\title{
ANALISIS CUSTOMER CHURN MENGGUNAKAN BAYESIAN BELIEF NETWORK (STUDI KASUS: PERUSAHAAN LAYANAN INTERNET)
}

\author{
Wildan Suharso, Arif Djunaidy \\ Jurusan Sistem Informasi, Fakultas Teknologi Informasi, Institut Teknologi Sepuluh Nopember \\ Keputih Sukolilo, Surabaya, 60111 \\ Telp : (031) 5994251, Fax : (031) 5923465 \\ E-mail:wsuharso@gmail.com
}

\begin{abstract}
The number of Internet users around the world tends to increase every year. However, the growth is not always accompanied by an increase in economy of scale for all types of telecommunication companies. For example, the Internet Service Providers have churn rates up to $30 \%$ per year. Therefore, many research on customer churn at telecommunications industry have been conducted. Among of these studies, there has no research specifically performed to analyze customer churn using Bayesian Belief Network (BBN) for the ISP. In this study, customer churn analysis for the Internet service providers was conducted by involving BNN method. Yet, prior to applying BNN, an outlier analysis was employed to eliminate extreme outliers that may contain in the data. The overall stages of customer churn analysis used in this study include data preparation, continuous variable discretization, outlier analysis, correlation analysis, multicollinearity test, and construction of causality and BBN diagrams.
\end{abstract}

Abstrak

Pertumbuhan pengguna Internet yang selalu meningkat tidak diikuti dengan peningkatan skala ekonomi untuk semua jenis perusahaan telekomunikasi. Salah satunya adalah perusahaan penyedia layanan Internet (ISP) yang memiliki laju churn hingga 30\% per tahun. Penelitian mengenai customer churn telah banyak dilakukan, tetapi belum ada penelitian yang menggunakan metode bayesian belief network (BBN) pada ISP. Dalam penelitian ini, analisis customer churn dilakukan dengan melibatkan metode BBN yang ditambahkan dengan analisis pencilan untuk menghilangkan data ekstrim. Tahapan analisis customer churn meliputi penyiapan data, diskritisasi variabel kontinyu, analisis pencilan, analisis korelasi, uji multikolinieritas, pembuatan diagram sebab-akibat, dan pembuatan BBN. Hasil penelitian menunjukkan bahwa data pelanggan personal dan pelanggan korporasi harus dilakukan analisis secara terpisah, analisis pencilan dapat menemukan variabel yang harus dikeluarkan sebelum analisis churn, analisis churn menemukan bahwa pemberian bonus pada pelanggan pesonal upto dapat menurunkan churn hingga 35\%, dan pada pelanggan quotabase hanya dapat menekan hingga $50 \%$.

Kata kunci: customer churn, Bayesian Belief Network (BBN), analisis pencilan (outlier), Internet Service Provider (ISP).

\section{PENDAHULUAN}

Pengguna Internet di seluruh dunia mengalami kenaikan setiap tahunnya (Arrepim Insight, 2012), begitupula dengan pengguna internet yang berada di kawasan Asia (Miniwatts Marketing Group, 2012). Selain peningkatan pengguna Internet terjadi pada semua jenis alat telekomunikasi (ITU, 2012), peningkatan juga terjadi pada industri Broadband (Pastore, 2005) sehingga juga terjadi kenaikan pendapatan pada industri broadband (Pitsikalis, 2008).

Pada benua Asia, Indonesia merupakan negara tertinggi keempat di wilayah Asia dalam penggunaan Internet. Terlebih lagi, Indonesia merupakan negara terbesar keenam pengguna
Internet di dunia (Miniwatts Marketing Group, 2012). Pengguna Internet di Indonesia terus mengalami peningkatan, kecenderungan baru muncul akibat peningkatan pengguna Internet, terjadi peningkatan 35\% pada tahun 2011 (Markplus Insight, 2011). Pada akhirnya, di tahun 2012 pengguna Internet di Indonesia mencapi 61 juta jiwa dan mayoritas adalah usia muda (Markplus Insight, 2012).

Dalam kaitannya dengan media internet yang digunakan, Indonesia merupakan negara pengakses Internet melalui perangkat nirkabel terbanyak di Asia (Nielsen, 2012). Pada tahun 2011 penggunaan perangkat nirkabel untuk mengakses Internet mengalami peningkatan sebesar 57,4\% (Markplus Insight, 2011), dan 
pada tahun 2012 mencapai 58 juta jiwa (Markplus Insight, 2012).

Industri telekomunikasi menjadi sektor dengan pertumbuhan tertinggi di Indonesia (Data Statistik Bidang Pos dan Telekomunikasi, 2010), tetapi tidak semua jenis perusahaan telekomunikasi mengalami peningkatan skala ekonomi, salah satunya adalah ISP. Peningkatan jumlah lisensi ISP yang dikeluarkan berbanding terbalik dengan peningkatan skala ekonomi ISP (Konsorsium Wimax Indonesia, 2009). Oleh karena itu, penelitian ini memiliki fokus pada ISP.

Peningkatan skala ekonomi hanya terjadi pada ISP berskala nasional dan perusahaan telekomunikasi yang bergerak pada semua bidang telekomunikasi, yang meliputi penyelenggara jaringan bergerak, penyelenggara jaringan tetap, dan penyelenggara jasa Asia (Securities, 2009; Data Statistik Bidang Pos dan Telekomunikasi, 2010).

Customer churn merupakan kecenderungan pelanggan ISP untuk berhenti berlangganan pada provider yang dipilih dan berpindah ke provider pesaing (Hadden, 2005). Laju churn pada ISP sebesar $10 \%$ perbulan dan diperkirakan setengah dari total pelanggan menghentikan layanan (Khan, 2010). laju churn pada industri telekomunikasi wireless sekitar $2,2 \%$ perbulan dan diperkirakan perusahaan kehilangan 27\% pelanggan setiap tahun (Wei dan Ciu, 2002). Banyak ISP mengakui bahwa laju churn perbulan adalah 2\% sampai 3\% perbulan atau $25 \%$ sampai $33 \%$ pertahun (Marsh, 2008). Laju churn pada ISP sangat tinggi, pada ISP berskala besar laju churn dapat lebih dari 30\%. Berdasarkan McPhillips (1999), biaya untuk mendapatkan pelanggan baru lebih besar daripada biaya untuk mempertahankan pelanggan. Oleh karena itu, perlu dilakukan upaya untuk mempertahankan pelanggan pada ISP.

Hasil pengamatan yang dilakukan pada ISP berskala nasional dan ISP berskala lokal menunjukkan bahwa terjadi penurunan skala ekonomi karena churn. Pada tahun 2009 terdapat 258 kasus penghentian layanan ISP oleh pelanggan hal ini mencapai porsi sebesar $40 \%$ dari jumlah tersebut yang berada hanya dalam satu wilayah yaitu jawa timur. Dari penghentian layanan ini, ISP mengalami kerugian sebesar Rp. 626.958.917. Dilain pihak total pelanggan aktif hingga tahun 2011 pada wilayah jawa timur adalah 97 pelanggan. Dari 97 pelanggan tersebut sebesar $36 \%$ merupakan pelanggan yang memulai berlangganan pada tahun 2011, dan sebesar $64 \%$ adalah pelanggan yang mulai berlangganan antara tahun 1999 sampai 2010. Hal ini menunjukkan bahwa jumlah pelanggan yang menghentikan layanan setiap tahunnya sangat tinggi dan terdapat kecenderungan pelanggan untuk menghentikan layanan dalam kurun waktu tertentu. Laju Churn yang tinggi juga terjadi pada ISP berskala lokal, hasil pengamatan awal pada dua ISP berskala lokal diketahui bahwa laju churn sebesar $31 \%$ dan $53 \%$.

Customer churn menjadi permasalahan utama pada perusahaan dengan jumlah pelanggan yang besar. Biaya yang dikeluarkan untuk memperoleh pelanggan baru lebih mahal dari biaya yang dikeluarkan untuk mempertahankan pelanggan yang sudah ada, sehingga customer churn menjadi senjata kompetitif dan landasan bagi perusahaan yang berfokus pada pelanggan (Richeldi \& Perrucci, 2002).

Berdasarkan paparan-paparan di atas maka dapat dilihat bahwa pertumbuhan pengguna Internet disebabkan oleh beberapa hal, antara lain karena kebutuhan dan kecenderungan masyarakat dalam menggunakan Internet. Kecenderungan baru muncul seiring dengan peningkatan tersebut, beberapa diantaranya adalah kecenderungan pengguna Internet untuk menggunakan peralatan nirkabel, Internet seluler, lokasi saat mengakses Internet, dan kecenderungan pengguna Internet di Indonesia untuk menggunakan paket Speedy dari Telkom.

Berdasarkan paparan di atas maka dapat disimpulkan bahwa pengguna Internet di seluruh dunia selalu mengalami kenaikan. Kecenderungan pengguna Internet turut mendorong pertumbuhan industri telekomunikasi secara umum, meskipun terjadi penurunan skala ekonomi pada penyelenggara telekomunikasi berjenis ISP. Laju churn yang telah ditemukan pada penelitian sebelumnya juga didukung oleh penelitian awal, yang menyimpulkan bahwa laju churn pada ISP sangat tinggi hingga mencapai $50 \%$ pertahun. Sehingga diperlukan penelitian mengenai customer churn pada ISP di Indonesia, selain dikarenakan penelitian customer churn pada ISP di Indonesia sangat jarang dilakukan.

Metode data mining telah digunakan pada penelitian-penelitian customer churn, namun belum ada yang menggunakan metode Bayesian Belief Network (BBN). Pemilihan metode BBN dikarenakan beberapa kelebihan, yaitu kemudahan untuk pendekatan heuristik dan analitis jika digunakan pada permasalahan yang kompleks atau permasalahan yang menggu- 
Suharso, dkk., Analisis Customer Churn Menggunakan Bayesian Belief Network...

nakan metode statistik yang membutuhkan data asli. Selain itu, data hilang atau tidak lengkap pada data set tidak menjadi permasalahan. Hubungan sebab akibat dapat diidentifikasi sehingga lebih mudah dalam memahami domain masalah serta pembangunan model tidak menghabiskan banyak waktu.

\section{METODOLOGI}

Bayesian belief network (BBN) merupakan salah satu metode data mining yang memiliki kelebihan dibandingkan pendekatan heuristik dan analitik (Heckermen, 1995). BBN membuat permasalahan lebih mudah untuk dipahami, serta pembangunan model tidak membutuhkan banyak usaha dan waktu, variabel baru dapat ditambahkan saat struktur dari jaringan dibangun, sampel data yang tidak lengkap bisa diperbaiki dengan menambahkan atau mengintegrasikan probabilitas dengan seluruh nilai yang mungkin dari variabel (Kisiouglu dan Topcu, 2011). BBN menjadi salah satu metode yang paling ampuh, sehingga BBN dapat digunakan pada area yang luas (Ouali dkk, 2006).

$\mathrm{BBN}$ belum pernah digunakan pada penelitian customer churn pada industri telekomunikasi (Kisiouglu dan Topcu, 2011), meskipun telah digunakan pada penelitian dengan topik yang lain, seperti yang telah dilakukan oleh Chang dan Lee (2009) untuk memprediksi kinerja dari box office pada industri film di Korea; Ulengin dkk (2007) untuk membangun model untuk diaplikasikan pada sistem transportasi di Turki; Marcot dkk (2001) menggunakan BBN untuk memodelkan habitat dan viabilitas populasi pada spesies ikan liar yang telah dipilih; Renken dan Mumby (2009) menggunakan BBN untuk mengintegrasikan proses-proses macroalgae (makro alga) dalam ekosistem terumbu karang dan memprediksi pertumbuhan microalgae (mikro alga) terumbu karang; Wang dkk (1999) menggunakan $\mathrm{BBN}$ untuk mendiagnosis kanker; McCann dkk (2005) memaparkan bahwa BBN merupakan alat yang sangat berguna untuk merepresenta-sikan pakar dari sebuah ekosistem, evaluasi dampak potensial dari manajemen pengambilan keputusan; Kisouglu dan Topcu (2011) menggunakan metode BBN untuk menjelaskan korelasi pada variabel yang memberikan efek pada customer churn pada telekomunikasi seluler.

\subsection{Model}

Model yang dibangun merupakan modifikasi model dari Kisouglu dan Topcu (2001) dengan menambahkan analisis pencilan, sehingga meliputi tahap persiapan data, diskritisasi variabel kontinyu, analisis pencilan, analisis korelasi, uji multikolinieritas, pembuatan diagram sebab-akibat, dan pembuatan BBN. Alur pembuatan riset ini ditunjukkan pada gambar 1. Perangkat lunak yang digunakan pada penelitian ini adalah Genie 2.0 untuk pembuatan BBN, Microsof Excel 2007 untuk analisis pencilan, dan XLStat 2013 trial license untuk mendiskritkan variabel kontinyu.

Pada gambar 1 dijelaskan bahwa model digambarkan ke dalam flowchart yang dimulai dengan tahapan persiapan data, yang meliputi pemilihan data, persiapan data dalam tabel, seleksi fitur, penentuan variabel. Analisis pencilan dilakukan setelah data telah siap dalam bentuk tabel. Analisis korelasi dan tes multikolinieritas dilakukan untuk menentukan nilai korelasi antar variabel, kemudian dibuat diagram kausalitas berdasarkan hasil dari analisis korelasi dan diskritisasi variabel kontinyu. Pembuatan BBN dilakukan berdasarkan tahapan pembuatan kausalitas.

Penyiapan data pada penelitian ini berbeda dengan penelitian pada industri seluler, karena perbedaan karakteristik data dan penggunaan jumlah objek penelitian. Pada penelitian ini digunakan 2 perusahaan sehingga penyiapan data menjadi lebih kompleks.

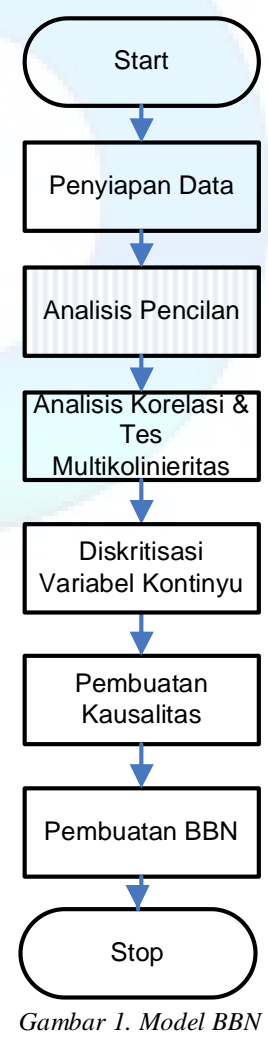


Tahapan penyiapan data membutuhkan waktu yang cukup lama karena data tidak bisa langsung digunakan pada penelitian. Data terdiri dari dokumen dan file yang masih terpisah berdasarkan nama pelanggan, sehingga tahapan penyiapan data meliputi beberapa sub tahapan, yaitu pemilihan data, persiapan data dalam tabel, seleksi fitur, penentuan variabel. Sub tahapan persiapan data dalam tabel meliputi proses penyalinan dokumen, rekap komplain, rekap data pelanggan. Sub tahapan seleksi fitur meliputi proses pembersihan data rekap komplain, pembersihan data rekap pelanggan, perekapan jumlah komplain.

\subsection{Data dan Variabel}

Semua data yang digunakan pada penelitian ini merupakan data yang berasal dari 2 perusahaan penyedia layanan Internet (ISP) berskala lokal, dikarenakan data dari ISP berskala nasional tidak lengkap dan kurang. Jumlah data adalah 431, data ini meliputi pelanggan korporasi dan personal. Jumlah variabel yang ditemukan adalah 14 dan yang digunakan adalah 11 variabel setelah melewati analisis pencilan, analisis korelasi, dan diskritisasi variabel kontinyu. Sebelas variabel tersebut adalah sebagai berikut :

- Jenis produk: jenis produk antara pelanggan personal dan pelanggan korporasi berbeda, pada pelanggan personal hanya ada upto dan quotabase, sedangkan pada pelanggan korporasi terdapat upto, dedicated, dan IIX

- Kecepatan: kecepatan setiap jenis produk didiskritkan menjadi 3 domain pada tahapan diskritisasi variabel kontinyu, yang pada awalnya setiap jenis kecepatan menunjukkan jenis produk yang berjumlah 17 jenis produk.

- Keterlambatan: variabel keterlambatan menunjukkan jumlah hari keterlambatan pembayaran.

- Harga Paket: menunjukkan harga jenis produk dan kecepatan yang dipilih

- Kekurangan: menunjukkan kekurangan pembayaran

- Perubahan akses: perubahan akses menunjukkan yang melakukan perubahan atau tidak

- Tambahan: menunjukkan pelanggan menambahkan akses layanan atau tidak

- Lama berlangganan: durasi pelanggan berlangganan dimulai dari pertama pemakaian langganan hingga penutupan layanan.

- Bonus: menunjukkan pelanggan mendapat bonus atau tidak

- Komplain: menunjukkan pelanggan melakukan komplain atau tidak

- $\underline{\text { Churn: }}$ menunjukkan pelanggan melakukan churn atau tidak
Penggunaan variabel pada penelitian ini berbeda dengan variabel yang digunakan oleh Kisiouglu \& Topcu (2011), variabel usia tidak digunakan karena usia tidak mempengaruhi pelanggan dalam memilih paket, pelanggan dibedakan berdasarkan personal dak korporasi. Pada penelitian ini juga digunakan variabel baru yang tidak digunakan oleh Kisiouglu \& Topcu (2011) yaitu variabel kecepatan, keterlambatan, tambahan, komplain dan bonus.

\subsection{Analisis Pencilan}

Analisis pencilan berhasil menemukan variabel yang seharusnya dihilangkan pada data set, yaitu terdaftar dan restitusi pada pelanggan korporasi, dan tambahan, terdaftar, restitusi pada pelanggan personal. Analisis pencilan menggunakan aturan nilai $\mathrm{z}$, dengan formula (1)

$$
Z_{i}=\frac{x_{i}-\mu}{\sigma}
$$

$Z_{i}$ adalah nilai pada data ke-i, $x_{i}$ adalah nilai data ke-i, , $\mu$ merupakan rata-rata kelompok data, $\sigma$ merupakan nilai standar deviasi.

Analisis pencilan juga terbukti memberikan kontribusi dengan menurunkan nilai korelasi antar variabel. Pada penelitian ini pembuatan diagram sebab-akibat berdasarkan nilai korelasi antar variabel. Dari hasil analisis pencilan juga ditemukan data ekstrim yang dapat menurunkan nilai korelasi. Setelah dilakukan analisis pencilan terdapat beberapa data yang dihilangkan sehingga data yang akan digunakan untuk proses berikutnya menjadi berjumlah 325 .

\subsection{Diskritisasi variabel kontinyu}

Diskritiasasi variabel kontinyu menggunakan perangkat lunak xlstat 2013, salah satu contohnya ditunjukkan pada tabel 1. Diskritisasi variabel kontinyu menggunakan algoritma fisher, sehingga diketahui kluster yang digunakan sebagai domain setiap variabel. Pada tabel 1 ditunjukkan contoh diskritisasi pada variabel kecepatan. Diskritisasi dilakukan pada semua variabel kontinyu.

Tabel 1. Diskritisasi Variabel Kontinyu Variabel Kecepatan

\begin{tabular}{|c|c|c|c|}
\hline Domain & 1 & 2 & 3 \\
\hline Jumlah Data & 16 & 2 & 8 \\
\hline $\begin{array}{l}\text { Within-class } \\
\text { Variance }\end{array}$ & 23969.067 & 0.000 & 0.000 \\
\hline $\begin{array}{l}\text { Jarak Minimum } \\
\text { Centroid }\end{array}$ & 25.000 & 0.000 & 0.000 \\
\hline $\begin{array}{c}\text { Jarak Rerata } \\
\text { Centroid }\end{array}$ & 119.250 & 0.000 & 0.000 \\
\hline $\begin{array}{c}\text { Jarak Maks. } \\
\text { Centroid }\end{array}$ & 287.000 & 0.000 & 0.000 \\
\hline
\end{tabular}


Suharso, dkk., Analisis Customer Churn Menggunakan Bayesian Belief Network...

\section{HASIL dan PEMBAHASAN}

Pada penelitian ini digunakan analisis korelasi dan tes multikolinieritas untuk membuat diagram sebab-akibat. Nilai korelasi pelanggan personal ditunjukkan pada tabel 2 dan nilai korelasi pelanggan korporasi ditunjukkan pada tabel 3. Diagram sebab-akibat yang dihasilkan adalah diagram sebab-akibat pelanggan personal yang ditunjukkan pada gambar 2, dan diagram sebab-akibat pelanggan korporasi yang ditunjukkan pada gambar 3 .

Pada gambar 2 ditunjukkan diagram sebabakibat pelanggan personal, dan pada gambar 3 ditunjukkan diagram sebab-akibat pelanggan korporasi. Diagram sebab-akibat antara gambar 2 dan gambar 3 berbeda karena perbedaan penggunaan variabel yang dihasilkan dari tahapan sebelumnya. Perbedaan ini menunjukkan bahwa diagram sebab-akibat antara pelanggan personal dan korporasi berbeda, sedangkan penelitian yang telah dilakukan sebelumnya oleh Kisiouglu dan Topcu (2011) tidak dilakukan pemisahan diagram sebab-akibat antara pelanggan personal dan pelanggan korporasi.

\subsection{Skenarioisasi}

Skenario dibangun berdasarkan tujuan dari penelitian, yaitu menentukan variabel yang berpengaruh pada penelitian. Pengembangan skenario ini dapat dijadikan rekomendasi pada perusahaan penyedia layanan Internet.

\subsection{Skenario 1}

Pada skenario 1 dilakukan uji coba untuk menentukan variabel yang berpengaruh langsung pada variabel churn, yang ditunjukkan pada gambar 4. Variabel yang berwarna putih menunjukkan variabel yang berpengaruh langsung pada churn pelanggan personal. Variabel ini ditunjukkan oleh kotak berwarna putih, sedangkan kotak biru merupakan variabel yang berpengaruh secara tidak langsung pada churn. Persentase churn sebesar $83 \%$ diperoleh jika persentase variabel kekurangan domain medium sebesar $100 \%$, persentase variabel bonus domain T_bonus adalah 100\%, 100\% pelanggan memilih kecepatan 2, $100 \%$ pelanggan memilih jenis produk quotabase, $100 \%$ pelanggan yang tergolong keterlambatan domain long, $100 \%$ pelanggan tidak melakukan komplain, dan semua pelanggan berlangganan dalam waktu yang pendek.

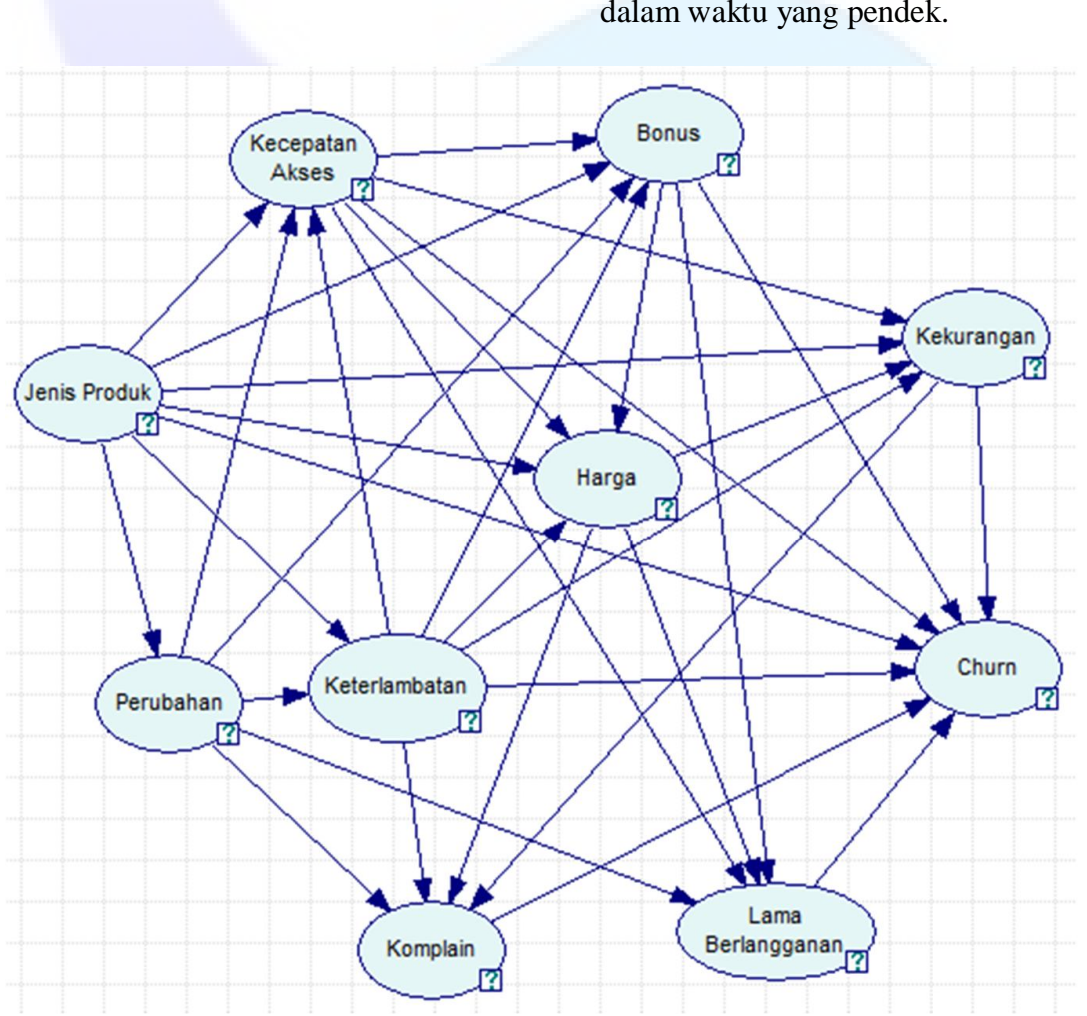

Gambar 2. Diagram Sebab-akibat Pelanggan Personal 
Jurnal Sistem Informasi, Volume 4, Nomor 5, September 2013, hlm 323-335

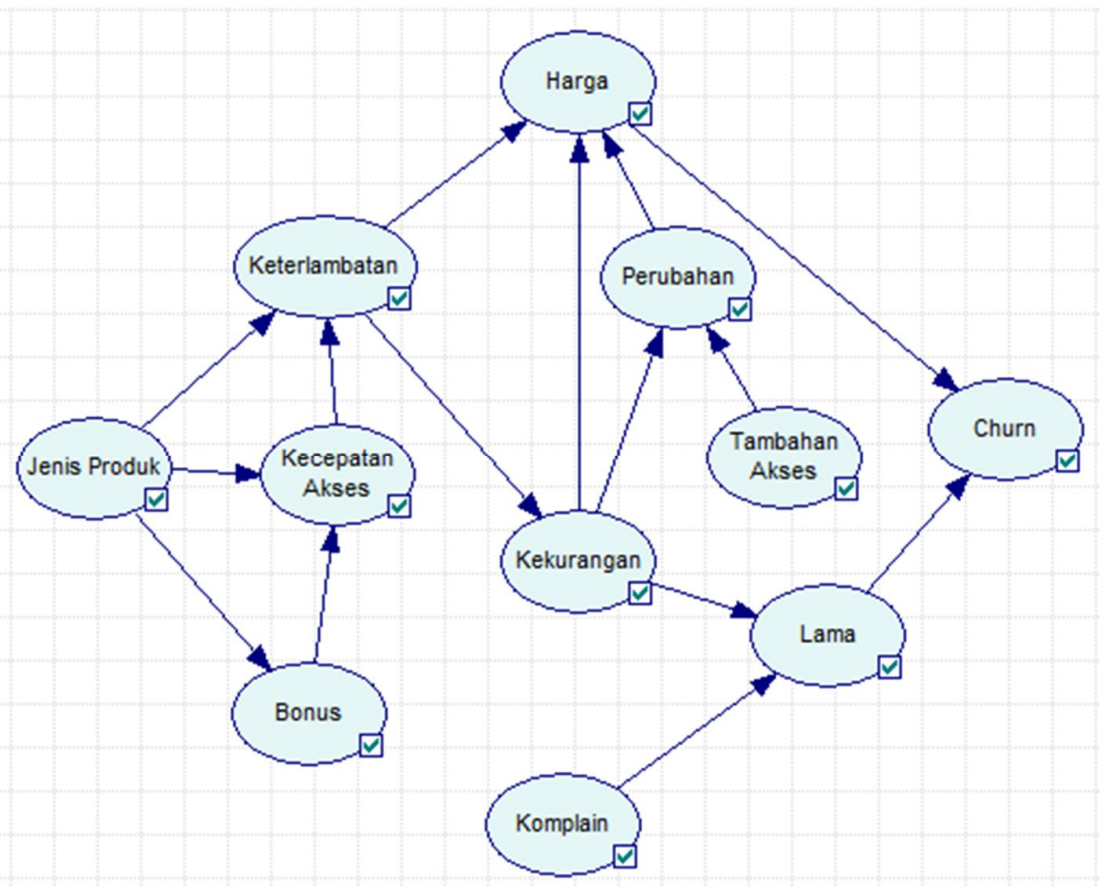

Gambar 3. Diagram Sebab-akibat Pelanggan Korporasi

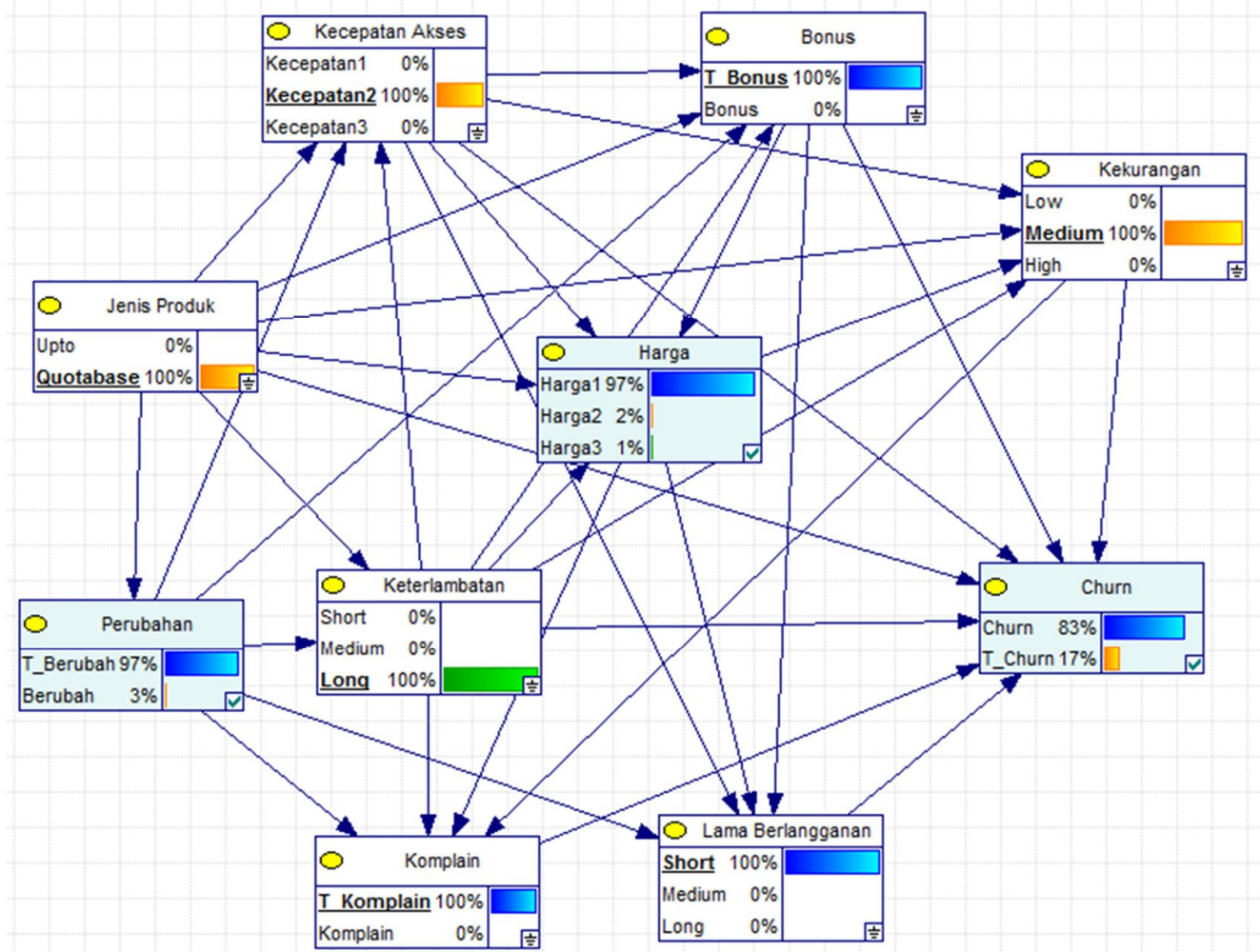

Gambar 4. BBN Skenario 1 Pelanggan Personal 
Suharso, dkk., Analisis Customer Churn Menggunakan Bayesian Belief Network...

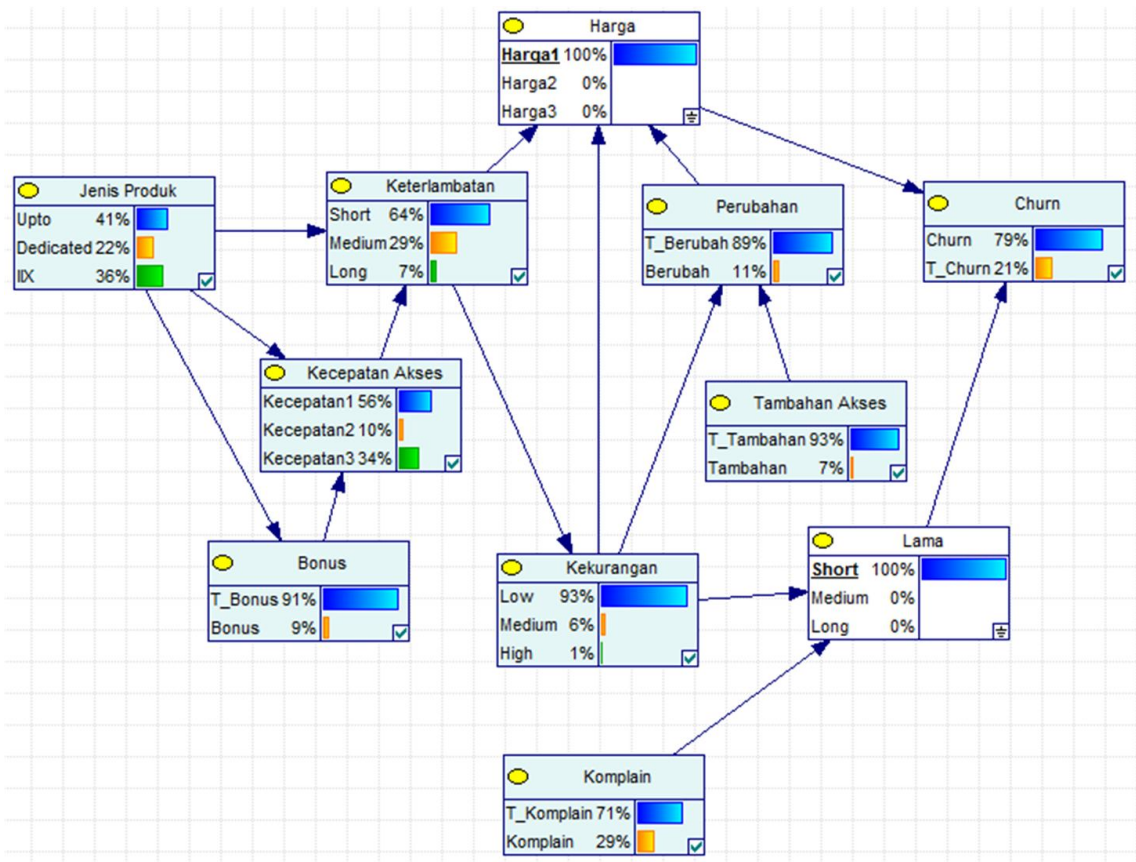

Gambar 5. BBN Skenario 1 Pelanggan Korporasi

Tabel 2. Korelasi Pelanggan Personal

\begin{tabular}{|c|c|c|c|c|c|c|c|c|c|c|c|}
\hline & & 1 & 2 & 3 & 4 & 5 & 6 & 7 & 8 & 9 & 10 \\
\hline \multirow[t]{2}{*}{1} & $\begin{array}{l}\text { Pearson } \\
\text { Correlation }\end{array}$ & 1 & $.923(* *)$ & $-.254(* *)$ & $-.114(*)$ & -.096 & .014 & $-.152(* *)$ & $-.157(* *)$ & -.091 & $-.143(*)$ \\
\hline & Sig. (2-tailed) & & .000 & .000 & .048 & .097 & .810 & .008 & .006 & .117 & .013 \\
\hline \multirow[t]{2}{*}{2} & $\begin{array}{l}\text { Pearson } \\
\text { Correlation }\end{array}$ & $.923(* *)$ & 1 & -.002 & $-.176(* *)$ & $-.170(* *)$ & -.006 & $-.268(* *)$ & $-.140\left(^{*}\right)$ & -.085 & $-.181(* *)$ \\
\hline & Sig. (2-tailed) & .000 & & .967 & .002 & .003 & .914 & .000 & .015 & .143 & .002 \\
\hline \multirow[t]{2}{*}{3} & $\begin{array}{l}\text { Pearson } \\
\text { Correlation }\end{array}$ & $-.254(* *)$ & -.002 & 1 & -.043 & $-.126(*)$ & -.006 & $-.240(* *)$ & .111 & .065 & -.052 \\
\hline & Sig. (2-tailed) & .000 & .967 & & .460 & .029 & .915 & .000 & .054 & .264 & .372 \\
\hline \multirow[t]{2}{*}{4} & $\begin{array}{l}\text { Pearson } \\
\text { Correlation }\end{array}$ & $-.114(*)$ & $-.176(* *)$ & -.043 & 1 & $.730(* *)$ & $.134(*)$ & $.147(*)$ & $-.150(* *)$ & .073 & -.015 \\
\hline & Sig. (2-tailed) & .048 & .002 & .460 & & .000 & .020 & .011 & .009 & .209 & .793 \\
\hline \multirow[t]{2}{*}{5} & $\begin{array}{l}\text { Pearson } \\
\text { Correlation }\end{array}$ & -.096 & $-.170(* *)$ & $-.126(*)$ & $.730(* *)$ & 1 & .061 & $.229(* *)$ & $-.219(* *)$ & .000 & -.041 \\
\hline & Sig. (2-tailed) & .097 & .003 & .029 & .000 & & .291 & .000 & .000 & .993 & .481 \\
\hline \multirow[t]{2}{*}{6} & $\begin{array}{l}\text { Pearson } \\
\text { Correlation }\end{array}$ & .014 & -.006 & -.006 & $.134(*)$ & .061 & 1 & $.174(* *)$ & .066 & .004 & $.157(* *)$ \\
\hline & Sig. (2-tailed) & .810 & .914 & .915 & .020 & .291 & & .003 & .252 & .950 & .006 \\
\hline \multirow[t]{2}{*}{7} & $\begin{array}{l}\text { Pearson } \\
\text { Correlation }\end{array}$ & $-.152(* *)$ & $-.268(* *)$ & $-.240(* *)$ & $.147(*)$ & $.229(* *)$ & $.174(* *)$ & 1 & $.130(*)$ & .066 & $.358(* *)$ \\
\hline & Sig. (2-tailed) & .008 & .000 & .000 & .011 & .000 & .003 & & .025 & .253 & .000 \\
\hline \multirow[t]{2}{*}{8} & $\begin{array}{l}\text { Pearson } \\
\text { Correlation }\end{array}$ & $-.157(* *)$ & $-.140(*)$ & .111 & $-.150(* *)$ & $-.219(* *)$ & .066 & $.130(*)$ & 1 & $.159(* *)$ & $.591\left(^{* *}\right)$ \\
\hline & Sig. (2-tailed) & .006 & .015 & .054 & .009 & .000 & .252 & .025 & & .006 & .000 \\
\hline \multirow[t]{2}{*}{9} & $\begin{array}{l}\text { Pearson } \\
\text { Correlation }\end{array}$ & -.091 & -.085 & .065 & .073 & .000 & .004 & .066 & $.159(* *)$ & 1 & .111 \\
\hline & Sig. (2-tailed) & .117 & .143 & .264 & .209 & .993 & .950 & .253 & .006 & & .055 \\
\hline \multirow[t]{4}{*}{10} & $\begin{array}{l}\text { Pearson } \\
\text { Correlation }\end{array}$ & $-.143(*)$ & $-.181(* *)$ & -.052 & -.015 & -.041 & $.157(* *)$ & $.358(* *)$ & $.591(* *)$ & .111 & 1 \\
\hline & Sig. (2-tailed) & .013 & .002 & .372 & .793 & .481 & .006 & .000 & .000 & .055 & \\
\hline & $\mathrm{N}$ & 299 & 299 & 299 & 299 & 299 & 299 & 299 & 299 & 299 & 299 \\
\hline & $\begin{array}{l}\text { Keterangan Tab } \\
\text { 1: Jenis Produk } \\
\text { 2: Kecepatan } \\
\text { 3: Harga }\end{array}$ & & & $\begin{array}{l}\text { 4: Kek } \\
\text { 5: Ket } \\
\text { 6: Per } \\
\text { 7: Bon }\end{array}$ & $\begin{array}{l}\text { Irangan } \\
\text { rlambatan } \\
\text { bahan }\end{array}$ & & & $\begin{array}{l}\text { 8: Churn } \\
\text { 9: Kompl } \\
\text { 10: Lama }\end{array}$ & & & \\
\hline
\end{tabular}


Jurnal Sistem Informasi, Volume 4, Nomor 5, September 2013, hlm 323-335

Table 3. Korelasi Pelanggan Korporasi

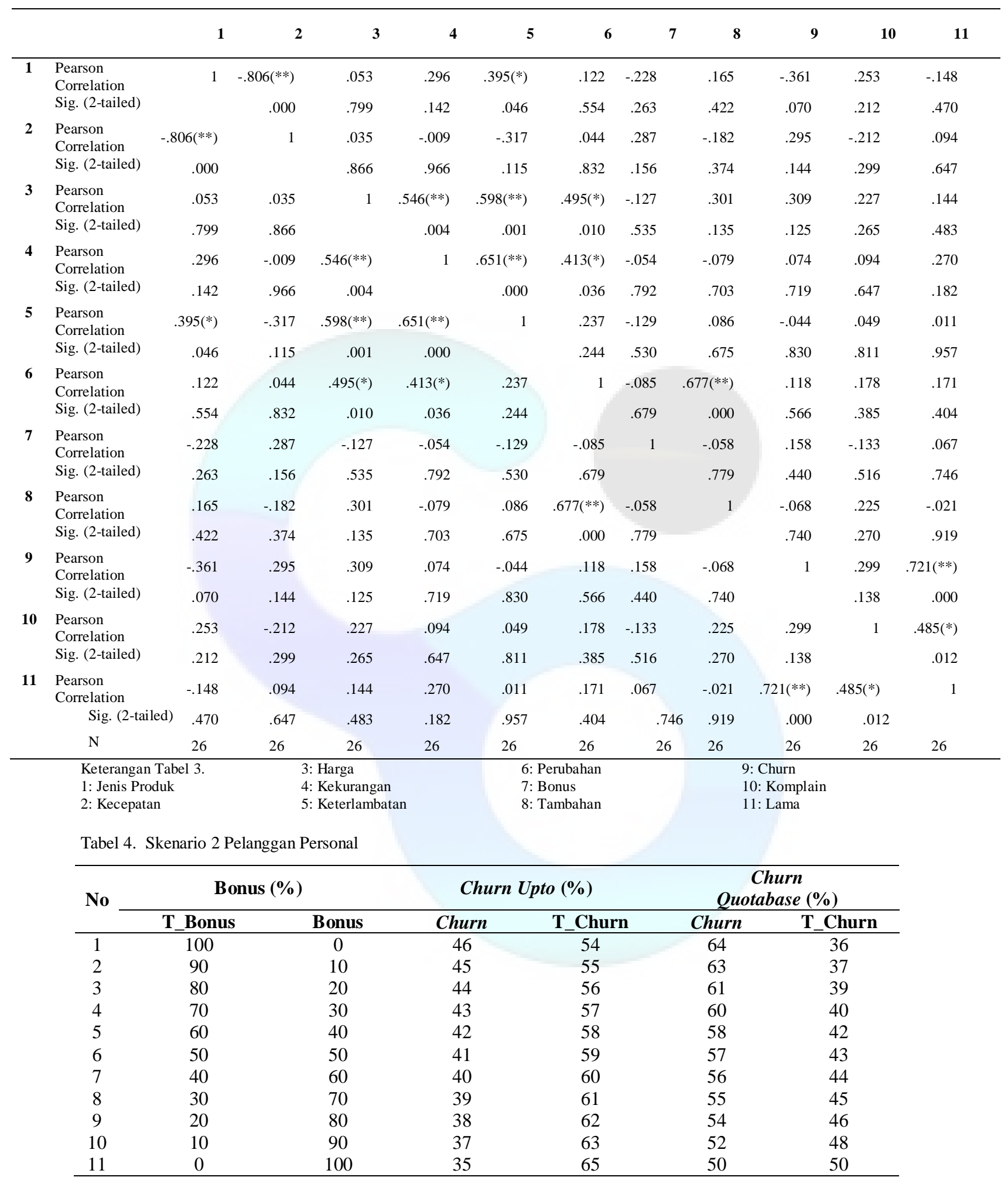


Suharso, dkk., Analisis Customer Churn Menggunakan Bayesian Belief Network...

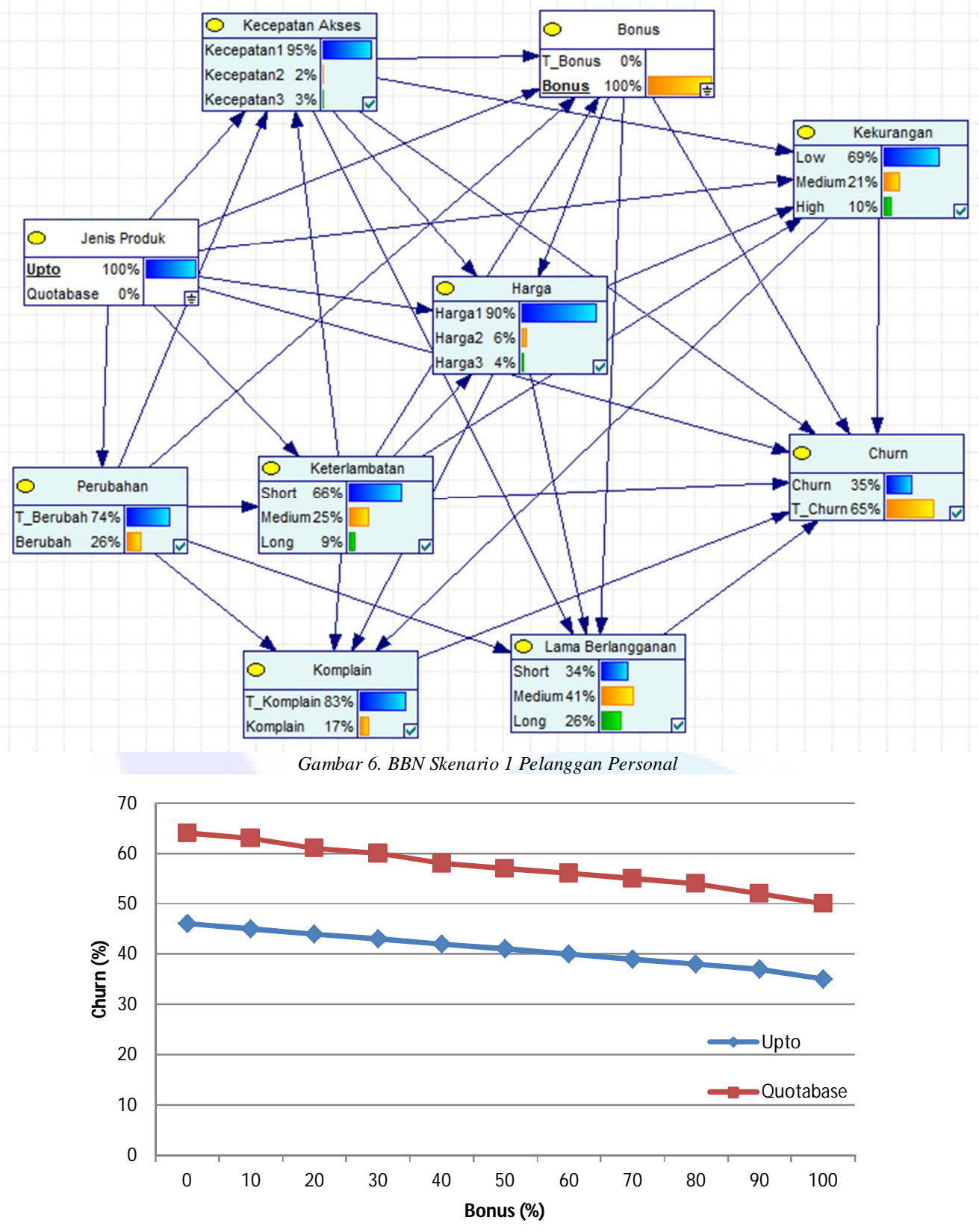

Gambar 7. Grafik Skenario 1 Pelanggan Personal

\subsection{Skenario 2}

Pemberian bonus pada pelanggan merupakan hal yang bisa dilakukan oleh perusahaan penyedia layanan Internet untuk meminimalkan churn secara langsung. Bonus diberikan pada jenis pelanggan upto dan quotabase secara terpisah untuk melihat perbedaan penurunan probabilitas churn. Dari hasil scenario 2 diketahui terdapat perbedaan perubahan persentase churn pada kedua jenis pelanggan tersebut. Penambahan bonus bernilai sama antara pelanggan upto dan quotabase, tetapi hasil yang diperoleh berbeda seperti yang ditunjukkan pada tabel 4. Penambahan bonus pada pelanggan "upto" dapat menurunkan persentase churn sebesar $11 \%$, sedangkan penambahan bonus pada pelanggan "quotabase" dapat menurunkan churn sebesar $14 \%$. Penurunan terbesar terjadi pada pemberian bonus pelanggan quotabase, sedangkan nilai churn terkecil yang diakibatkan oleh pemberian bonus adalah pada pelanggan upto. Persentase churn pada pelanggan upto sebesar 35\%, sedangkan persentase churn pada pelanggan quotabase dapat menekan nilai churn hingga $50 \%$. 
Persentase awal pelanggan upto yang mendapat bonus adalah $16 \%$ dari seluruh pelanggan upto, dengan nilai churn sebesar $45 \%$. Pemberian bonus pada pelanggan upto dapat menekan persentase churn hingga $35 \%$, sehingga setiap penambahan persentase bonus sebesar $10 \%$ pada pelanggan upto dapat menurunkan persentase churn sebesar 1\%. Grafik penurunan churn pada pelanggan personal ditunjukkan pada gambar 7 .
Pemberian bonus pada pelanggan korporasi tidak memberikan perubahan churn secara signifikan (Tabel 5). Pemberian bonus pada pelanggan upto tidak merubah persentase churn. Pemberian bonus pada pelanggan yang tergolong dedicated dapat menurunkan $1 \%$ pelanggan churn dari $42 \%$ ke $41 \%$ dengan syarat $80 \%$ pelanggan dedicated mendapat bonus. Pemberian bonus pada pelanggan IIX juga merubah persentase churn dari $42 \%$ menjadi $41 \%$, dengan syarat $40 \%$ pelanggan IIX diberi bonus.

Tabel 5. Skenario 2 Pelanggan Korporasi

\begin{tabular}{ccccccccc}
\hline \multirow{2}{*}{ No } & \multicolumn{2}{c}{ Bonus (\%) } & \multicolumn{2}{c}{ Churn Upto (\%) } & \multicolumn{2}{c}{ Churn Dedicated (\%) } & \multicolumn{2}{c}{ Churn IIX (\%) } \\
& T_Bonus & Bonus & Churn & T_Churn & Churn & T_Churn & Churn & T_Churn \\
\hline 1 & 100 & 0 & 42 & 58 & 42 & 58 & 42 & 58 \\
2 & 90 & 10 & 42 & 58 & 42 & 58 & 42 & 58 \\
3 & 80 & 20 & 42 & 58 & 42 & 58 & 42 & 58 \\
4 & 70 & 30 & 42 & 58 & 42 & 58 & 42 & 58 \\
5 & 60 & 40 & 42 & 58 & 42 & 58 & 41 & 59 \\
6 & 50 & 50 & 42 & 58 & 42 & 58 & 41 & 59 \\
7 & 40 & 60 & 42 & 58 & 42 & 58 & 41 & 59 \\
8 & 30 & 70 & 42 & 58 & 42 & 58 & 41 & 59 \\
9 & 20 & 80 & 42 & 58 & 42 & 58 & 41 & 59 \\
10 & 10 & 90 & 42 & 58 & 41 & 58 & 41 & 59 \\
11 & 0 & 100 & 42 & 58 & 41 & 58 & 41 & 59 \\
\hline
\end{tabular}

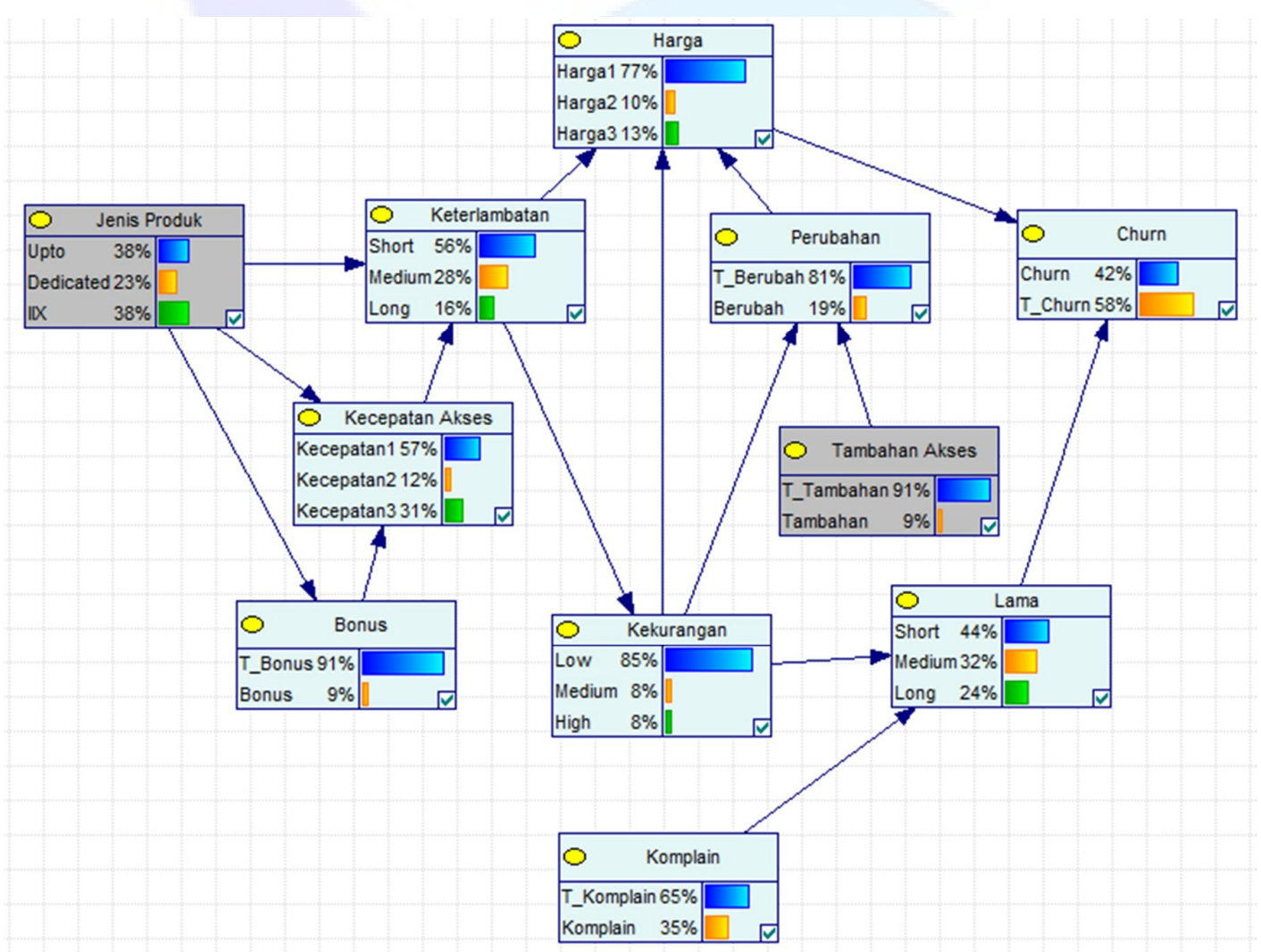

Gambar 8. BBN Skenario 3 Pelanggan Korporasi 
Tabel 6. Skenario 3 Pelanggan Korporasi

\begin{tabular}{ccccccccc}
\hline \multirow{2}{*}{ No } & \multicolumn{2}{c}{ Tambahan Akses (\%) } & \multicolumn{2}{c}{ Churn Upto $(\%)$} & \multicolumn{2}{c}{ Churn Dedicated (\%) } & \multicolumn{2}{c}{ Churn IIX (\%) } \\
& T_Tambah & Tambah & Churn & T_Churn & Churn & T_Churn & Churn & T_Churn \\
\hline 1 & 100 & 0 & 43 & 57 & 42 & 58 & 42 & 58 \\
2 & 90 & 10 & 42 & 58 & 42 & 58 & 42 & 58 \\
3 & 80 & 20 & 42 & 58 & 42 & 58 & 42 & 58 \\
4 & 70 & 30 & 42 & 58 & 42 & 58 & 42 & 58 \\
5 & 60 & 40 & 42 & 58 & 42 & 58 & 42 & 58 \\
6 & 50 & 50 & 42 & 58 & 42 & 58 & 41 & 59 \\
7 & 40 & 60 & 42 & 58 & 42 & 58 & 41 & 59 \\
8 & 30 & 70 & 42 & 58 & 41 & 59 & 41 & 59 \\
9 & 20 & 80 & 42 & 58 & 41 & 59 & 41 & 59 \\
10 & 10 & 90 & 41 & 59 & 41 & 59 & 41 & 59 \\
11 & 0 & 100 & 41 & 59 & 41 & 59 & 41 & 59 \\
\hline
\end{tabular}

\subsection{Skenario 3}

Skenario 3 hanya dilakukan pada pelanggan korporasi karena pada Hasil skenario 2 pelanggan korporasi menunjukkan bahwa pemberian bonus pada semua jenis pelanggan tidak memberi pengaruh besar pada churn, sehingga pada uji coba ini dikembangkan skenario baru. Berdasarkan tahapan penyusunan skenario dijelaskan bahwa pengembangan skenario harus dapat diplikasikan pada perusahaan penyedia layanan Internet, sehingga skenario tidak hanya dilakukan dengan merubah parameter BBN.

Pada gambar 8 ditunjukkan bahwa kotak yang berwarnan abu-abu adalah variabel tambahan akses dan jenis pelanggan, sehingga diketahui pemberian tambahan akses dapat menurunkan churn pada pelanggan korporasi.

Berdasarkan skenario 3 diketahui bahwa pemberian promosi berupa akses tambahan hanya mempengaruhi persentase churn sebesar maksimal 2\%. Pemberian tambahan akses kepada pelanggan upto hanya berpengaruh sebesar $2 \%$, pemberian tambahan akses pada pelanggan dedicated hanya berpengaruh pada churn sebesar 1\%, dan pemberian akses tambahan pada pelanggan IIX hanya berpengaruh pada churn sebesar $1 \%$.

\section{SIMPULAN dan SARAN}

Pada penelitian ini diketahui bahwa analisis pencilan dapat menurunkan nilai korelasi variabel yang digunakan, dan nilai korelasi digunakan untuk menentukan hubungan sebabakibat yang berguna pada pembuatan BBN. Pada perusahaan penyedia layanan Internet diketahui bahwa terdapat perbedaan karakte- ristik jenis pelanggan, yang ditunjukkan dengan hasil setiap tahapan pada penelitian, variabel yang digunakan pada jenis pelanggan personal dan korporasi berbeda, diagram sebab-akibat juga memiliki perbedaan, dan hasil skenario antara jenis pelanggan juga berbeda.

Variabel tambahan tidak digunakan pada pelanggan personal. Variabel paket tidak bisa digunakan karena pada penelitian ini dilakukan pemisahan antara analisis pelanggan personal dan pelanggan korporasi, sehingga nilai-Z dan koefisien korelasi variabel paket bernilai null. Variabel restitusi tidak digunakan karena dihapus saat melewati analisis pencilan.

Analisis pencilan dapat menghapus data yang tergolong ekstrim, jika data pelanggan personal dan korporasi digabung maka banyak data yang seharusnya disimpan tetapi dihapus oleh analisis pencilan. Analisis pencilan dapat meningkatkan nilai korelasi antar variabel, analisis pencilan dapat menunjukkan bahwa pada pelanggan personal tidak diperlukan variabel akses tambahan.

Pemberian bonus pada pelanggan personal kelompok upto dapat menurunkan churn hingga $35 \%$, sedangkan pada kelompok pelanggan quotabase hanya dapat menekan churn hingga $50 \%$. Pemberian bonus pada pelanggan korporasi kelompok upto tidak memberikan perubahan persentase churn, pada kelompok dedicated dapat menurunkan churn sebesar $1 \%$, dan pada kelompok IIX dapat menurunkan churn sebesar $1 \%$. Pemberian tambahan akses kepada pelanggan korporasi kelompok upto dapat menurunkan churn sebesar 3\%, pada kelompok dedicated dan IIX dapat menurunkan churn sebesar $1 \%$. 


\section{DAFTAR RUJUKAN}

Agrawal, M.L., 2003. Customer Relationship Management (CRM) \& Corporate Renaissance. Journal of Services Research, Vol. 3, Number 2, pp. 149-171.

Areppim Insight, 2012. Global Internet Users Forecast2012,http://stats.areppim.com/arch ives/insight_internetxfcstx2012.pdf.

Gallagher, C.A., Monroe, H.M., Fish, J.L., 2000. An Iterative Approach to Classification

Analysis,www.casact.org/library/ratemakin g/90dp237.pdf, 27 Maret 2012.

Gujarati, D.C., 2004. Basic Econometrics, $4^{\text {th }}$ ed., The McGraw-Hill Companies.

Gunesh, R., 2005. Correlation analysis, http://pages.intnet.mu/cueboy/education /notes/statistics/pearsoncorrel.pdf, 14 Maret 2012.

Gursoy, U.T.S., 2010. Customer Churn Analysis In Telecommunication sector, Istanbul University Journal of the School of Business Administration, Vol 39, No 1, pp. 35 - 49, ISSN: 1303-1732.

Hadden, J., Tiwari, A., Roy, R., Ruta, D. 2005. Computer Assisted Customer Churn Management: State Of The Art And Future Trends, Science Direct, Computer \& Operations Research, Vol 34, pp. 2902 2917.

Heckerman, D., 1996. A Tutorial on Learning With Bayesian Network. Microsoft Research,

http://research.microsoft.com/pubs/69588/tr -95-06.pdf, Desember 2011.

Hung, S.Y., David, C.Y., Wang, H.Y., 2006. Applying Data Mining To Telecom Churn Management, Science Direct, Expert Systems with applications, volume 31, pp. 515-524.

Huang, B., Kechadi, M.T., Buckley, B., 2012. Customer Churn Prediction In Telecommunications, Science Direct, Expert Systems with Application, volume 39, pp. 1414-1425.

International Telecommunication Union (ITU), 2010. Monitoring The WSIS Targets: A mid-term review, World Telecommunication/ICT

Development Report 2010, Geneva Switzerland, http://www.uis.unesco.org/Communication/ Documents/ WTDR2010_e.pdf, November 2011.
International Telecommunication Union (ITU), 2012. Measuring The Information Society, Geneva Switzerland, http://www.itu.int/ITU-

D/ict/publications/idi/material/2012/MIS20 12_without_Annex_4.pdf, 17 November 2012

Kass, G.V., 1980. An Exploratory Technique for Investigating Large Quantities of Categorical Data, Applied Statistic, Vol. 29, pp. 119-127.

Keramati, A., Ardabili, Seyed, M.S., 2011. Churn Analysis for an Iranian Mobile Operator, Science Direct, Telecommunications Policy, Volume 35, pp. 344-356

Key, J.P., 2002. Research Design in Occupational Education, Oklahoma State University,http://www.okstate.edu/ag/agedc m4h/academic/aged5980a/5980/ newpage26.htm, 15 maret 2012.

Khan, A.A., Jamwal, S., Sepehri, M.M., 2010. Applying Data Mining to Customer Churn Prediction in an Internet Service Provider, International Journal of Computer Applications, Volume 9 - No. 7, 21 November 2010.

Kisioglu, P., Topcu, Y.I., 2011. Applying Bayesian Belief Network Approach to Customer Churn Analysis: A Case Study on The Telecom Industry of Turkey. Science Direct, Expert Systems with Applications, Volume 38, pp. 7151-7157.

Kriegerl, H.P., Schubert, M., Zimek, A., 2008. Angle-Based Outlier Detection In HighDimensional Data, Proc. Of The 14th ACM SIGKDD International Conference On Knowledge Discovery \& Data Mining (KDD’08), 444 - 452, Las Vegas.

Lee, E., Park, Y., Shin, J.G., 2009. Large Engineering Project Risk Management Using a Bayesian Belief Network, Expert System with applications 36 (2009), pp. 5880-5887.

Lehmann, T., Eherler, D., 2001. Responder Profiling with CHAID and Dependency Analysis.

Liao, T.W. dan E. Triantaphyllou, (Eds.), Recent Advances in Data Mining of Enterprise Data: Algorithms and Applications, World Scientific, Singapore, pp. 1-109, 2007.

Liu, H., Yu, L., 2005. Toward Integrating Feature Selection Algorithms For Classification And Clustering, IEEE 
Suharso, dkk., Analisis Customer Churn Menggunakan Bayesian Belief Network...

Transaction On Knowledge And Data Engineering, Vol 17, No 4.

Marcot, B. G., Houthausen, R.S., Raphael, M.G., 2001. Using Bayesian Belief Network to Evaluate Fish and Wildlife Population Viability Under Land Management Alternatives from an Environmental Impact Statement, Forest \& Ecology Management 153 (2001), pp. 2942.

Markplus Insight, 2012. Indonesia's Most Favorite Netizen Brand 2012, http://themarketeers.com/archives/indonesias-mostfavorite-netizen-brand-2012.html, $\quad 17$ November 2012.

McPhilips, E., 1999. The Structure And Trends Of The ISP Market, University Of Strathclyde, Glasgow And Helett-Packard Laboratories, Bristol.

Miniwatts Marketing Group, 2012. Internet Users In The World 2012, http://www.internetworldstats.com/stats.ht m, 17 November 2012.

Montgomery, D.C., Runger, G.C., 2003. Applied Statistics and Probability for Engineers, $3^{\text {rd }}$ ed., John Wiley \& Sons, Inc.

Ngai, E.W.T., Xiu, X., Chau, D.C.K., 2009. Application Of Data Mining Techniques In Customer Relationship Management, Elsevier, Expert System With Applications, Expert Systems With Applications, Vol 36, pp. $2592-2602$.

Oseman, K.B., Shukori, S.A.B., Harisi, N.A., Bakari, F.B.A., 2010. Data Mining In
Churn Analysis Model For Telecommunication Industry, Journal Of Statistical Modeling And Analytics, Vol 1 No. 19-17.

Parvatiyar, A., Sheth, J.N., 2001. Customer Relationship Management: "Emerging Practice, Process, and Discipline”, Journal of Economic and Social Research 3(2) 2001, pp. 1-34.

Pitsikalis, C., 2008. Internet Evolution and Service Providers Business Models, Athens Information Technology, Greece.

Renken, H., Mumby, P.J., 2009. Modelling the Dynamics of Coral Reef Macroalgae Using a Bayesian Belief Network approach, Ecological Modelling 220, 1305-1314.

Richeldi, M., Perrucci, A., 2002. Churn Analysis Case Study, Telecom Italia Lab, http://www.ai.cs.unidortmund.de/PublicPub licationFiles/richeldi_perrucci_2002b.pdf,D esember 2011.

Telkom.co.id, 2012. Hari Pelanggan Nasional 2012: Telkom Berikan Layanan Ekstra, http://www.telkom.co.id/pojokmedia/siaran-pers/hari-pelanggan-nasional 2012-telkom-berikan-layanan-ekstra.html, 5 Desember 2012.

Wilson, H.E., Daniel, E.M., McDonald, M.H.B., 2002. Factors for Success in Customer Relationship Management (CRM) Systems, Journal of Marketing Management, Vol. 18, pp. 193-219. 